\title{
大振幅下における圧電セラミックの力学的挙動 (圧電セラミックトランスの場合)*
}

\author{
生島 \\ Mechanical Behavior of Piezoelectric Ceramics \\ under Large Amplitude Operation \\ (The Piezoelectric Ceramic Transformer Case)
}

弘 志**

by

\section{Hiroshi IkUSHIma}

(Wireless Research Laboratory Matsushita Electric Industrial Co. Ltd., Kadoma)

\begin{abstract}
Mechanical properties of piezoelectric ceramic transformers were investigated as an example of the dynamic behavior of piezoelectric ceramics under large amplitude operation. The static and dynamic strengths were measured on the driver and generator sections of the transformer. The difference in heat production between the sections was recognized, which proved to be derived from an orientation discrepancy between the poling and stressing directions.

A large non-linearity common to the mechanical strength and the heat-generation phenomenon was found to be associated with the non-linearity in resonance characteristics of resonators.

Mechanical fracture of piezoelectric ceramic transformers, which is the ultimate event under large amplitude stress, occurred mainly in the secondary portion. This phenomenon is understandable from the difference in static tensile strength between the primary and secondary portions.

The mechanical strength of piezoelectric ceramics also depended on their grain size as in the case of other ceramics. The propagation path of the crack generated was transgranular or intergranular depending upon grain size. Griffith cracks were hardly observed in any specimen tested. The existence of etch pits, which may be due to dislocations, was discovered for the first time in piezoelectric ceramics. Strain-hardening was also recognized.

From the above experimental results, a new model for the mechanical break-down mechanism in piezoelectric ceramics was proposed.
\end{abstract}

キー・ワード : 圧電セラミック, 非線形現象, 破壊機構

(Received Mar. 24, 1981)

\section{1 序論}

圧電セラミックは, 素体に印加される電気信号によ って応力が発生し, 逆に素体に応力が加わると電気信 号を発生するもので, 磁気セラミックと並んで能動的 な機能を有するセラミックである. 電子回路に拉ける 圧電セラミックは, フィルタや振動子のように, 比較 的小振幅下に沶いて使用されるので, その力学的挙動 を問題とされることは少い, しかるに, 圧電セラミッ クの応用分野が拡がるにつれて, 超音波トランスデュ 一サーを代表例として大振幅下での使用が増えつつめ る.

本分野に打ける従来の研究は, 代表的な圧電セラミ

* 原稿受理 昭和 56 年 3 月 24 日

** 正会 員 松下電器産業(株)無線研究所 門真市大字門真
ックである PZT セラミックにおいて, 機械的質係数 $\left(Q_{M}\right)$ の挙動を中心に行われてきだ しかし, 圧電せ ラミックの大振幅下での力学的挙動の正確な 把握に は未だ及ばざる所が多い，例壳ば，動的変位を直接に 観察した報告はなく，乙たがって振動モードを直観的 に把觉ることもなされないますである，一方，圧電振 動子の小型化を図る限り非線形性の問題を避けて通れ ない.内部摩擦は非線形性を支配する重要な因子であ るが，この定義があいまいなままで使用されて扣り， 物性論的考察がない. したがってあくまで現象論に留 まり，実体の把握に努めていない. 藤島らは，圧電七 ラミック振動子の応力限界や許容入力について, 先駆 的仕事を発表している。しかしながら，エネルギ密度 を振動子の断面積当りで考皇るのは正しくなく，かつ 
それを素体全体に積分しても意味がない。なぜなら， 共振状態にある振動子では, 常に応力極大点があり, その近傍での力学的挙動こそが, 材料強度学的立場特 よび振動論的立場の双方にとって本質的なものだから である. 高橋らは, 電わい定数を大振幅下で連続測定 しながら, 非線形性の問題や内部摩擦への立入った考 察を忞っている. 更に, 機械的な破壊機構についての 正確なデータに基づく考察も未だなされていない.

圧電セラミックトランスは, C. A. Rosenによって 最初に考案されたもので, 電気一機械括よび機械一電気 変換の両機能を一体化してかつ大振幅下で発揮する点 でその力学的挙動が大いに注目されてよい.

\section{2 理 論}

\section{$2 \cdot 1$ 圧電トランスの構成}

压電トランスは Rosen 以来, 多くの研究者によっ て実用化が試みられてきている。圧電トランスの構成 と動作を一言にして表すならば, 一次側に蓄えた静電 エネルギを逆の圧電効果によって弾性エネルギとして 二次側に伝送し, 一次側の静電容量に比べて二次側の それを充分小さくすることにより, 二次側で正の圧電 効果により高い出力電圧を得ようとするるので, 一次 側と二次側の各部分は通常一体化されている. これを 図で示せば Fig. 1 のようなものである. 斜線で示し た電極を用いて矢印 $(P)$ の方向に分極処理して始めて 圧電トランスとして機能し得るものとなる. 実際の使 用回路では, 二次側に整流と負荷の両回路が接続され る.

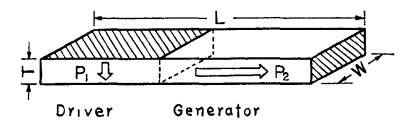

Fig. 1. Figure of piezoelectric transfomer.

本研究で用いられた素材は，二成分系の PZT と同 じ鉛酸化物であるが，三成分系である点に特長を有す る強誘電セラミックである(以下, PCM と略称する).

\section{$2 \cdot 2$ 圧電トランスの動作基本方程式}

圧電トランスの基本動作を規定するものは，压電基 本式と Newton の運動方程式である. Fig. 1 の素体 の長さ方向のみの振動変位を取り扱ら一軸近似を採る ことにより, 一次側は $d$-形式, 二次側は $g$-形式をそ れぞれ用いて次式のよらに表される。すなわち，

$$
\begin{array}{r}
T_{1}=\left(1 / s_{11}{ }^{E}\right) \cdot S_{1}-\left(d_{31} / s_{11}{ }^{E}\right) \cdot E_{3} ; \partial E_{3} / \partial x=0 \\
(\text { 一次側 }) \quad(1) \\
T_{3}=\left(1 / s_{33}{ }^{D}\right) \cdot S_{3}-\left(g_{33} / s_{33}{ }^{D}\right) \cdot D_{3} ; \partial D_{3} / \partial x=0
\end{array}
$$$$
\text { (二次側） (2) }
$$

(1)，(2)式に㧊いて添字 $(1 \sim 3)$ は, Fig.1 のトラン ス素体の各部分に拈ける $P_{1}, P_{2}$ の各方向を添字 3 と した場合に対応する。ただし， $x$ 一軸は各部分に共通で
素体の長さ方向に採っている.

\section{$2 \cdot 3$ 等価回路設計における問題点}

トランスとして所要の昇王比を得るためには，(1), (2)式と Newton の運動方程式から等価回路を導き, 負荷条件に応じた形状設計を行ら必要がある.テレビ ジョン受像機に拈いて用いられる昇圧トランスの場合 は, 特に小型化と高効率駆動が要求される. したがっ てかかる際には非線形領域にまで立入った設計が必要 となる. 等価回路設計に際しては, 負荷回路をどの程 度まで精細に考慮して採り入れるか（例觉ば浮遊容量 等）によって,トランスの形状寸法にも無視できない 効果が現れる. いずれにせよ前提となる仮定は次の四 つである.

(1) トランス素体の長さ方向の振動変位に比べて幅 および厚みの各方向のそれは無視できる程度に小さい (一軸近似).

（2）駆動部と発電部の $Q_{M}$ は等しいものとする.す なわち,

$$
Q_{M(d)} \simeq Q_{M(g)}
$$

（3）駆動部と発電部の機械的特性インピーダンスが 等しい.すなわち

$\rho_{d} v_{d} A_{(d)}=\rho_{g} v_{g} A_{(g)} \quad(v:$ 速度, $A$ : 断面積 $)$

(4) 駆動部と発電部の長さ方向の位相伝ぱ量が等し い.すなわち

$$
\begin{aligned}
& L_{d} v_{d}=L_{g} v_{g} \\
& 3 \text { 実 験 結 果 }
\end{aligned}
$$

\section{$3 \cdot 1$ 圧電セラミックの機械的強度}

$3 \cdot 1 \cdot 1$ 圧電セラミックにおける各種の強度 圧 電トランスは，動作中に毎秒 $10^{4} \mathrm{~Hz}$ 以上という短い 周期で, 引張りと王縮の繰返し荷重をらける. セラミ ックにおいては，一般にその压縮強度 $\left(\sigma_{c}\right)$ は引張強 度 $\left(\sigma_{t}\right)$ の数十倍にも及ぶので, 圧電トランスの強度 を規定するものは $\sigma_{t}$ であると言える. ところで, セ ラミック一般に $\sigma_{t}$ の測定は簡単でなく従来から曲げ 強度 $\left(\sigma_{b}\right)$ が代用されてきた. 筆者らも, 当初各種の PCM材について $\sigma_{b}$ を測定して Table I の結果を得 た. Table I の結果和よび既に公表されている圧電セ ラミックのデータから筆者は次の半実験式を得た.す なわち,

Table I. Bending strength in piezoelectric ceramics.

\begin{tabular}{l|r|r}
\hline & PCM-71 & \multicolumn{1}{|c}{ PCM-80 } \\
\hline Grain size $(\mu)$ & $2 \sim 7$ & $05 \sim 3$ \\
Primary portion $\left(\mathrm{kg} / \mathrm{cm}^{2}\right)$ & $1250 \sim 1270$ & $1440 \sim 1460$ \\
Secondary portion $\left(\mathrm{kg} / \mathrm{cm}^{2}\right)$ & $900 \sim 920$ & $760 \sim 780$ \\
\hline
\end{tabular}

$$
\sigma_{t} / 2=\left(\sigma_{b}+\sigma_{c} / m\right) \cdot(1+m)^{-1}, \quad(m=9 \sim 10)
$$

(3)式から推定される $\sigma_{t}$ は PCM セラミックに和いて, 
Table II. Material constants of the specimen.

\begin{tabular}{c|c|c|c|c|c|c}
\hline & $\begin{array}{c}\text { Density } \\
\left(\rho: \mathrm{kg} / \mathrm{m}^{3}\right)\end{array}$ & $\begin{array}{c}\text { Poisson's ratio } \\
(\boldsymbol{\sigma})\end{array}$ & $\begin{array}{c}\mathrm{S}_{11} \boldsymbol{E} \\
\left(\mathrm{m}^{2} / \mathrm{N}\right)\end{array}$ & $\begin{array}{c}\mathrm{S}_{33} D \\
\left(\mathrm{~m}^{2} / \mathrm{N}\right)\end{array}$ & $\begin{array}{c}\mathrm{d}_{31} \\
(\mathrm{~m} / \mathrm{V})\end{array}$ \\
\hline PCM-71 & 7700 & $0.29_{0}$ & $122 \times 10^{-12}$ & $931 \times 10^{-12}$ & $-126 \times 10^{-12}$ & $256 \times 10^{-3}$ \\
PCM-80 & 7900 & $0.28_{2}$ & $114 \times 10^{-12}$ & $7.75 \times 10^{-12}$ & $-121 \times 10^{-12}$ & $25.5 \times 10^{-3}$ \\
\hline
\end{tabular}

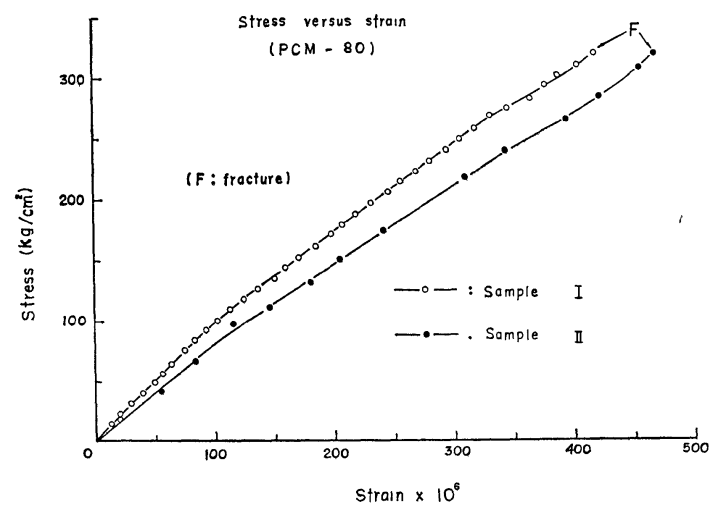

Fig. 2. Tensile strain versus tensile stress.

$300 \mathrm{~kg} / \mathrm{cm}^{2}$ 以上と見積られる. Table I で明らかな ことは二次側の $\sigma_{b}$ が一次側に比べて小さいといらこと である. したがって, 压電トランスの強度の推定は二 次側に执いて行兄ば充分であり，改めてこの部分の引 張試験を行って実測值 $320 \mathrm{~kg} / \mathrm{cm}^{2}$ を得た。

この結果を Fig. 2 亿示す. Fig. 2 はいずれの試片 も注涪 $320 \mathrm{~kg} / \mathrm{cm}^{2}$ という引張応力下で破断した（記 号Fで示されている) ことを示している．興味深いの は, 引張応力の 増加とともにひずみ一応力の直線性が やや非直線化することで，塑性変形の可能性を示唆し ている. この問題は $3 \cdot 4$ 節で改めて考える.

$3 \cdot 1 \cdot 2$ 压電トランスにおける応力 圧電トラン スの動作条件は, 素片の 全長に 定在する音波の波長 (入)の数によりさまざまに分れる. 全長に一波長が定 在する入モードでは，一次側拈よび二次側の各部分の 長さ方向に沿った中央付近に応力の極大点が存在する. 実際汇は，機械的破壊の大部分が二次側のほぼ中央近 傍に集中する．これには，大きく二つの理由が考觉ら れる.

（1）残留ひずみの方向が，二次側では応力の方向と 同じである. トランス素材の圧電セラミック $(\mathrm{PCM})$ は，元来変位型の強誘電性セラミックで自発ひずみを もっている．したがって，応力の方向に平行なひずみ が内在している二次側は, 同一応力下でも一次側より 破壊しやすいと推定される.

（2）動作中では，二次側の応力が一次側のそれょり 大きいと考えられる。これを圧電基本式から見積って みよう，そのために必要な材料定数を Table II に与 えて和く，実は，(1)，(2)式の右辺の第2 項はそれぞれ
第 1 項に比べ約 2 桁小さい量であり無視できて次式を 得ることができる。すなわち，

$$
T_{1} / T_{3}=\left(S_{1} / S_{3}\right) \cdot\left(S_{33}{ }^{D} / S_{11}{ }^{E}\right)
$$

一方, 変位の連続性から,

$$
\begin{aligned}
& u_{1}=L_{1} S_{1}=u_{3}=L_{3} S_{3} \\
& \therefore \quad S_{1} / S_{3}=L_{3} / L_{1}
\end{aligned}
$$

更に, 前節で述べた四つの仮定の内, 筆者らによるト ランス表面のクラドニ図形の観測により確められた位 相伝ば量の連続性から，

$$
L_{1} / v_{1}=L_{3} / v_{3}
$$

(4) (6)式加

$$
T_{3} / T_{1}=\left(v_{1} / v_{3}\right)\left(s_{11}{ }^{E} / s_{33}{ }^{D}\right)=\left(s_{11}{ }^{E} / s_{33}{ }^{D}\right)^{1 / 2}
$$
ただし，一様媒質として $\rho_{d}=\rho_{g}\left(\rho_{1}=\rho_{3}\right)$ としている. Table II からわかると赫り， $s_{33}{ }^{D}$ は $s_{11}{ }^{E}$ に比べ約 20 〜30\%小さいので(7)式から, 二次側部分での最大応力 $\left(T_{3}\right)$ は一次側のそれ $\left(T_{1}\right)$ より十数\%以上大きくな ることがわかる。

つぎに二次側の最大応力は一次側入力電流に比例す

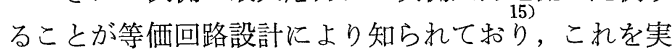
験的に確めた結果を Fig. 3 亿示す.

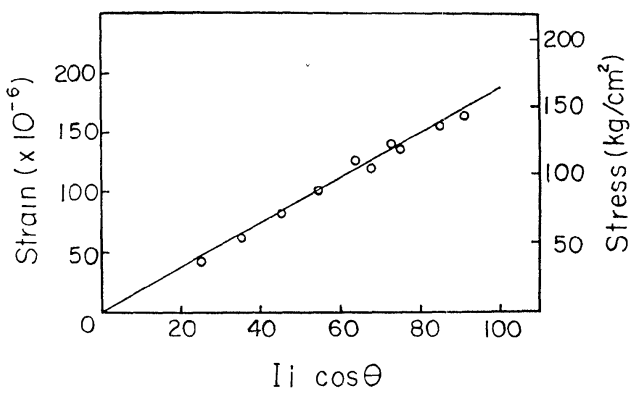

Fig. 3. Dynamic stress \& strain versus input current.

\section{$3 \cdot 2$ 圧電トランスにおける発熱現象}

\section{$3 \cdot 2 \cdot 1$ 圧電トランスにおけるエネルギの流れ}

圧電トランスに打けるエネルギの流孔は, Fig.4の ごときものであり，出力に和ける放電や音響叔よび電 磁波の輻射エネルギは極めて小さいことが実験的に知 られ，また圧電トランスに定在している振動のェネル ギも計算から出力の千分の一以下と知孔る. そこで, 圧電トランスに怙けるェネルギ変換効率を評価するに は Fig. 4 に拈りる熱エネルギを測定することが必要 である. 


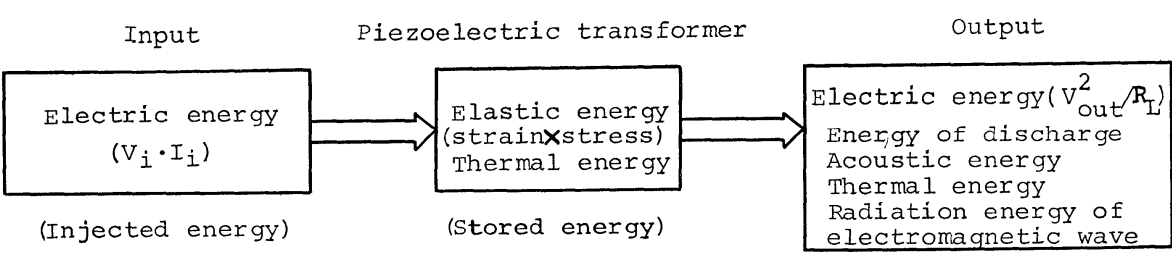

(Ejected energy)

Fig. 4. Energy transfer in piezoelectric transformer.

\section{$3 \cdot 2 \cdot 2$ 発熱の空間分布 压電トランスの動作中} に和ける発熱の状態は，被観測系を観測によってでき る限り乱さないという philosophy に基づいて，一定 時間の動作終了直後に, 赤外輻射温度計によって静止 状態に括汀る空間分布として捉えた。入モードにおけ

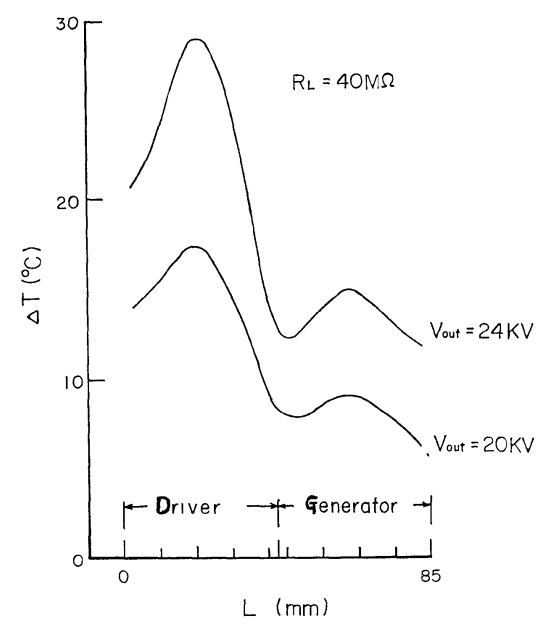

Fig. 5. Spatial distribution of heat-generation in $\lambda$-mode (in length direction).

る代表的な結果を Fig. 5 亿示す。同図に和ける $\Delta T$ は，実測温度から雾囲気温度を差し引いたものである。 従来, 压電トランスの発熱の空間分布をトランスの全 長にわたって測定した例はなくFig. 5 によって我及 もまた始めて一次側と二次側部分に和ける明確な差異 を知ったのである。これらの発熱は，180-分域壁の 法線方向に応力が働き，圧電効果に伴うひずみによっ て壁の面積が変化し, 結晶の異方性のエネルギが摩擦 熱として解放されると考支られる. 異方性のエネルギ は, 圧電トランス素体が強誘電性セラミックで本来自 発ひずみによる弾性エネルギを有することから生ずる のである.

\section{$3 \cdot 3$ 圧電トランスにおける非線形現象}

$3 \cdot 3 \cdot 1$ 振動子の共振特性 压電トランスに批 るエネルギ変換効率を最も端的に示すものは $Q_{M}$ の大 振幅特性である. Table II に示した PCM セラミッ クからなり Fig. 1 のごとき形状の試片において，一次 側部分は出力端開放の条件下で, 二次側部分は出力端
に負荷が接続された条件下での特性の代表例を Fig. 6 (a)，(b)にそれぞれ示す。曲線の peak 值は，圧電体と しての共振インピーダンスに対応して標準抵抗に流れ る電流値に相当するものであり，パラメータとして示 した励振電圧が増加するにつれ，その振幅が一定の割 合で増加しなくなり，共振周波数が低周波側へずれる ことがわかる。これらの現象は，圧電体法ける非線 形現象として知られている。非線形性を論ずるには，

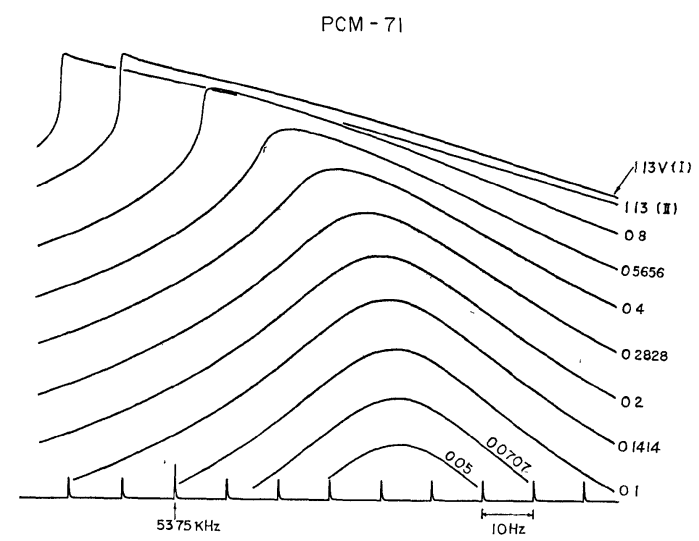

(a) Driver portion (PCM-71)

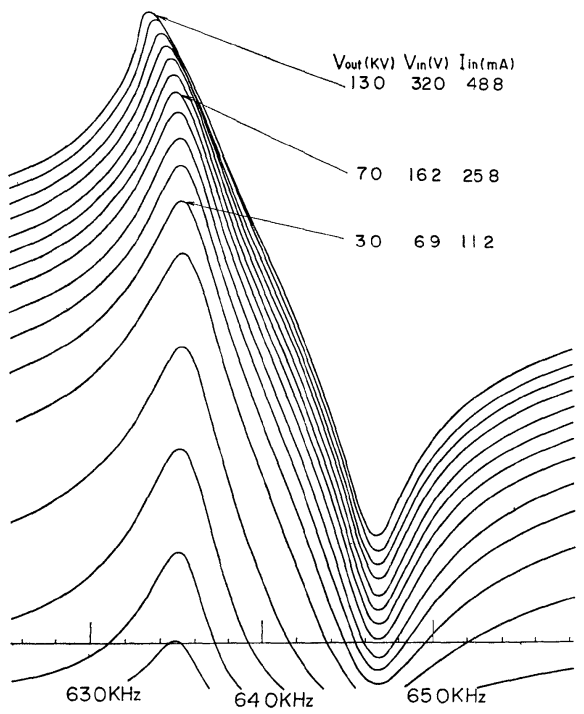

(b) Generator portion (PCM-80)

Fig. 6. Large amplitude property of $Q_{M}$ in piezoelectric ceramic transformer. 
まずその系の線形限界点を見定めることが必要と思わ れるが，Fig. 6 に示したように $Q_{M}$ の大振幅特性は出 力端に接続される負荷回路によって相当大幅に変るも のである、したがって，一定動作条件下に和ける線形 限界点を比較的正確に知ることが難しくなり一義的に $Q_{M}$ ないしは内部摩擦 $\left(Q_{M}{ }^{-1}\right)$ を得ることも困難とな る.

\section{$3 \cdot 3 \cdot 2$ 異常温度上昇と線形限界 大振幅振動下} の圧電セラミックの発熱は, セラミック内部に定在す る弾性エネルギの一部が内部摩擦によって熱エネルギ に転換したものと考光てよい. Fig. 3 に示したように， ひずみ（または応力）は入力電流に一次比例するから 内部損失としての熱ェネルギは入力電流に二次比例す ると予想される，そこでこの両者の関係を求めた結果 の代表例がFig. 7 である. Fig. 7 から求めた線形限界 点に括ける発熱による温度上昇分とひずみ一応力を Table III に示す. Table III に拈ける $\Delta T$ とSは実 測値であり，Tはこの $S$ を圧電基本式(1)，(2)に代入乙

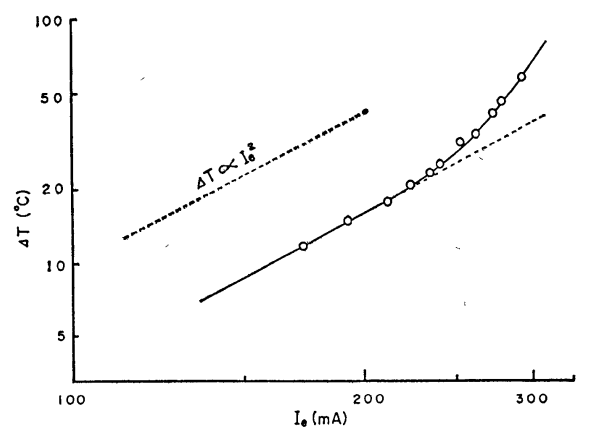

Fig. 7. Surface temperature increase versus input current.

Table III. Critical points of linear region (PCM-80).

\begin{tabular}{|c|c|c|c|c|c|c|}
\hline & \multicolumn{2}{|c|}{$\Delta T\left({ }^{\circ} \mathrm{C}\right)$} & \multicolumn{2}{|c|}{$S(\mu$ strain $)$} & \multicolumn{2}{|c|}{$T\left(\mathrm{~kg} / \mathrm{cm}^{2}\right)$} \\
\hline & Driver & Generator & Driver & Generator & Driver & Generator \\
\hline A & $\lesssim 25$ & $\lesssim 10_{4}$ & $\lesssim 150$ & $\lesssim 150$ & $\lesssim 134$ & $\lesssim 193$ \\
\hline B & $\lesssim 25$ & $\$ 10$ & $\lesssim 183$ & $\$ 160$ & $\lessgtr 160$ & $\$ 204$ \\
\hline $\mathrm{C}$ & $\lesssim 25$ & $\lesssim 14$ & $\lesssim 150$ & $\lessgtr 133$ & $\lesssim 134$ & $\$ 163$ \\
\hline
\end{tabular}

(A : $56 L \times 7 W \times 3.5^{T}, \mathrm{~B}: 75 L \times 20 W \times 3 T, \mathrm{C}: 85 L \times 12 W \times(2.3$ $\times 3) T$, unit : $\mathrm{mm}$ )

Table IV. Internal friction of piezoelectric transformer (PCM-80).

\begin{tabular}{c|c|c|c|c}
\hline & \multicolumn{2}{|c|}{$Q_{M^{-1}}$} & \multicolumn{2}{c}{$Q_{M}$} \\
\cline { 2 - 5 } & Driver & Generator & Driver & Generator \\
\hline A & $\simeq 1.1 \times 10^{-3}$ & $\simeq 3.5 \times 10^{-4}$ & $\simeq 09 \times 10^{3}$ & $\simeq 28 \times 10^{3}$ \\
B & $\simeq 1.0 \times 10^{-3}$ & $\simeq 37 \times 10^{-4}$ & $\simeq 1.0 \times 10^{3}$ & $\simeq 2.7 \times 10^{3}$ \\
C & $\simeq 1.6 \times 10^{-3}$ & $\simeq 8.7 \times 10^{-4}$ & $\simeq 06 \times 10^{3}$ & $\simeq 1.1 \times 10^{3}$ \\
\hline
\end{tabular}

て求めた。な拉，Fig.7 は Table III の試料Cの場 合に相当する. 更に，トランス各部の応力最大点に和 ける単位体積当りの熱エネルギ $\left(E_{\text {thermal }}\right)$ と弾性エネ ルギ $\left(E_{\text {elastic }}\right)$ を Table III のデータを用いて計算し， 内部摩擦を一周期の間に弾性エネルギの熱に変る割合 として，本来の物理的な意味に立ち帰って求めた結果 が Table IV である. Table IV によって, 従来不明 確であった圧電セラミックの内部摩擦が明確に定義さ れたことになる.なお, Table IV の $Q_{M}$ は圧電トラ ンスの各部分を個別な素体として電気的に測定した值 とよく一致した。これによって, 非線形現象は単位体 積当りある一定量以上のエネルギを内部摩擦によって 損失することによって生ずるといら解釈が得られる。

\section{$3 \cdot 4$ 圧電トランスにおける破壊の様相}

$3 \cdot 4 \cdot 1$ マイクロ・クラック伝ぱの様相 セラミ ック一般のごとく, 機械的強度の粒径依存性を調べる ことは甚だ困難な作業である．岡崎らは，この困難な 仕事に精力的に取り組み，金属や一般のセラミックに おけると同様な強度の粒径依存式を実験的に得ている. 我々の実験に用いた試料では, 引張強度 $\left(\sigma_{t}\right)$ で PCM71 に比べて粒径の小さい PCM-80 が約 $10 \%$ 近く, 大 きな值を有するといら結果を示し，粒径の大小によっ て，、イクロ・クラック伝ぱ径路が粒界および粒内に 分れる。

$3 \cdot 4 \cdot 2$ ひずみ一硬化の現象 $3 \cdot 1 \cdot 1$ 節に括ける Fig. 2 の結果を仔細に見ると, わずかな塑性変形の後, 破断に到る前の段階で若干の変形応力の増加が認めら れる. 一定荷重の引張試験を, トランスの二次側素片 に対して 繰返し行ったところ，一種のひずみー硬化の 効果が現れた.

$3 \cdot 4 \cdot 3$ エッチピットの発見と破壊機構 圧電セ ラミックが常温・常圧で塑性変形を起すとすれば, 内 部に動き得る転位が存在してもよい. 更にグリフィス ・クラックの存在がほとんど認められないことから， ガラスや特にもろいセラミック等で言われるグリフィ ス・クラック模型は, 圧電セラミックの破壊機構に対 しては適用され難いことになる，そこで，転位に対応 すると予想されるピットの発見に努めた，新しい腐食 液を用いて強誘電セラミミックでは始めて, エッチピッ トが見出された.

これらのピットの一定応力下での可動性を調べるこ とはできなかったが, 応力変化に伴う密度の変化は観 察できた.

あえて, 我々の観察したピットを転位によるものと すれば，圧電セラミックの内でも特に高密度・高効率 の電気一機械変換媒体としての PCM セラミックの破

* 修酸溶液にかなりのフッ酸を混入したもの. 分域や粒径観察に常 用される腐食液は微量のフッ酸入り硝酸溶液. 
壊機構としては, グリフィス・クラック模型ではなく， 転位模型の可能性が大きいと言光よう。すなわち, 破 壊の起点は, セラミック粒界の移動集積し得る転位に より発生したマイクロ・クラックであり，破壊の形式 は完全なぜい性ではなく，ミクロ一塑性の可能性があ ることから，延性的性質も有すると言える.

$$
4 \text { 結 論 }
$$

本研究によって得られた結果を以下に要約する.

\section{$4 \cdot 1$ 圧電トランスに特有なこと}

(1) トランスの二次側に生じる最大応力は, 一次側 のそれより若干大きいために，トランスの破斀は二次 側の最大応力点近傍に集中する.

（2）内部摩擦による振動子としての非線形性や発熱 は, 二次側より一次側において著しい。

（3）等価回路模型は，上記の結果を本来予測できな い.したがって、トランスの設計に際して本研究のよ うな物理的アプローチの助けを借りて補正を行らこと が大切である.

\section{$4 \cdot 2$ 圧電セラミック一般に共通すること}

(1) 圧電セラミックの内部摩擦に主として寄与する るのは, 誘電損失や振動のエネルギではなく, 強誘電 セラミックの分域壁の運動である.

（2）微小粒径を有する高密度・高効率圧電セラミッ クは大振幅下でミクロー塑性変形を示し，その破壊機 構は若干の延性を持ち, 転位模型の可能性がある.

(3) 圧電セラミックに拈ける非線形現象拉よび機械 的破壞は, セラミック素体の単体の単位体積当りに蓄 えられる弾性エネルギが一定限界を越えたときに起る。

本研究によって, 大振幅下にある圧電セラミックの 力学的挙動はかなり明確になったと言えよう.

本研究の成果は, 当社で数年前になされた压電卜ラ ンスの開発過程で得られたもので, 筆者に本研究の機 会を与兄られた当社技術本部長早川取締役ならびに, 結果の発表を許可された当社開発本部長兼無線研究所 所長飯田常務取締役に深甚の謝意を表します.

材料の提供に対しては, 当社材料研究所大内主幹研 究員之西田研究員に, 等価回路模型の教示に対しては, 同じく伊勢室長に, また実験の協力に対しては同じく 黄地研究員にそれぞれ感謝します。

（昭和56年 3 月13日 第 5 回セラミック材料部門委員会にて講演）

\section{参 考 文 献}

1) Gerson, R., J. Acous. Soc. Amer., 32, 1297 (1960).

2) Krueger, H. H.A., and D. Berlincourt, J. Acous. Soc. Amer., 33, 1339 (1961).

3) 藤島 啓, 筧 流石, 電子通信学会 - 超音波研究専門委 員会資料 (1962).

4) Whymark, R. R., J. Acous. Soc. Amer, 45, 587 (1969).

5) Yamauchi, F., and M. Takahashi, J. Phys. Soc. Japan., 28, 313 (1970).

6) 高橋純夫, 森 栄司, 日本音響学会誌, 29, 100 (1973).

7）八鉜和夫, 電子通信学会論文誌, J 60-A， 978 (1977).

8) Rosen, C. A., Proc. Elec. Comp. Symp., 205(1956).

9) Katz, H. W., "Solid State Magnetic \& Dielectric Davice”, Chap. IV (1959) John Wiley \& Sons. Inc., New York

10) 土屋英俊, 電学誌, 81, 603 (1961).

11) Van Berkum, P.A., et al., I. R.E. Trans. on B.T. R. 8, 22 (1962).

12) Ohuchi, H., et al., J. Amer. Ceram. Soc., 48, 630 (1965).

13) Berlincourt, D. A., et al., "Physical Acoustics", Chap. 3 (1964) ed. by Mason, W. P., Academic Press, New York \& London

14）安細恭弘, 森木寿夫, 1973年テレビジョン学会予稿集, 10-15, 281 (1973).

15）要 祐一, 伊勢悠紀彦, 日本音響学会誌, 32, 470(1976).

16) 岡崎 清, “セラミック誘電体工学”, 第10章 (1969) 学 献社

17) Ikushima, H., and K. Ohji, Japanese J. Appl. Phys., 13, 28 (1974).

18) Ikushima, H., and K. Ohji, Proc. 1st Meeting on Ferroelectric Materials and Their Applications, 211 (1978).

19) Stokes, R. J., "Ceramic Microstructures", Chap. 16 (1968) ed. by Fulrath, R. M., and J.A. Pask, John Wiley \& Sons. Inc., New York

20) Davidge, R.W., and A. G. Evans, Mater. Sci. Eng., 6, 281 (1970).

21）岡崎 清, 永田邦裕, 電子通信学会 - 電子回路部品 - 材 料研究会資料, 資料番号 CPM 71-21 (1971).

22) 生島弘志, 日置康弘, 他, 日本物理学会講演, 誘電体部 門, 255 (1973). 